\title{
Esophageal eosinophilia in pediatric patients with cerebral palsy
}

\author{
Eosinofilia esofágica em pacientes pediátricos com paralisia cerebral
}

\author{
Ana Carolina Ramos de Nápolis ${ }^{1}$, Flavia Araujo Alves ${ }^{1}$, \\ Erica Rodrigues Mariano de Almeida Rezende ${ }^{1}$, Gesmar Rodrigues Silva Segundo ${ }^{1}$
}

\begin{abstract}
Objective: To describe the clinical picture, test results, and clinical evolution of patients with cerebral palsy associated with diagnosis of eosinophilic esophagitis, monitored at tertiary centre. Methods: Cross-sectional, retrospective and descriptive study that evaluated the medical records data of pediatric patients with diagnosis of cerebral palsy and eosinophilic esophagitis in a tertiary center of pediatric gastroenterology between August 2005 and August 2013. Results: Seven out of 131 patients with cerebral palsy had the diagnosis of eosinophilic esophagitis. The mean age at diagnosis of eosinophilic esophagitis was 52.3 months and the mean number of eosinophils in esophagus was 35 per high-power field. Symptoms more frequent were recurrent vomiting and disphagia. Endoscopic alterations found were mucosal thickening, vertical lines, mucosal opacificacion and white plaques. Conclusion: The frequency of eosinophilic esophagitis found was higher than in general pediatric population. The investigation of eosinophilic esophagitis should be done regularly in those patients, once this entity could overlap other gastrointestinal diseases.
\end{abstract}

Keywords: Cerebral palsy/complications; Eosinophilic esophagitis/etiology; Stomach diseases; Gastroesophageal reflux; Child

\section{RESUMO}

Objetivo: Descrever quadro clínico, resultados dos exames e evolução clínica de pacientes com paralisia cerebral associada ao diagnóstico de esofagite eosinofílica, monitorados em um centro terciário. Métodos: Estudo transversal, retrospectivo e descritivo, que avaliou os prontuários médicos de pacientes pediátricos com diagnóstico de paralisia cerebral e esofagite eosinofílica, atendidos em um centro terciário de gastrenterologia pediátrica, entre agosto de 2005 e agosto de 2013. Resultados: Dos 131 pacientes com paralisia cerebral, 7 tiveram 0 diagnóstico de esofagite eosinofílica no período estudado. A idade média no momento do diagnóstico de esofagite eosinofílica foi 52,3 meses, e 0 número médio de eosinófilos no esôfago foi de 35 por campo de grande aumento. Os sintomas mais frequentes associados foram vômitos recorrentes e disfagia. As alterações endoscópicas encontradas foram espessamento da mucosa, linhas verticais, opacificação da mucosa e as placas esbranquiçadas. Conclusão: A frequência de esofagite eosinofílica encontrada foi maior que na população pediátrica em geral. A investigação de esofagite eosinofílica deve ser realizada regularmente nos pacientes com paralisia cerebral, pois pode haver uma sobreposição de sintomas de outras doenças gastrintestinais.

Descritores: Paralisia cerebral/complicações; Esofagite eosinofílica/ etiologia; Gastropatias; Refluxo gastroesofágico; Crianças

\section{INTRODUCTION}

Eosinophilic esophagitis (EE) is a disease diagnosed based on clinical and histological parameters. The condition is defined by symptoms of esophageal dysfunction, predominantly eosinophilic inflammation with esophageal biopsy eosinophil count $\geq 15$ per highpower field (hpf), restricted to the esophagus, and unchanged after a 2-month course of proton pump inhibitors (PPI). ${ }^{(1)}$ This entity was first described in the late 1970 s by Landers et al. ${ }^{(2)}$ and presumed as a clinicopathologic entity in 1993, by Attwood et al. ${ }^{(3)}$ Despite the large number of publications in recent years, there are still many questions surrounding this pathology. $\mathrm{EE}$ is frequently associated with other atopic diseases, such as asthma, allergic rhinitis, atopic dermatitis, and food allergies. ${ }^{(1)}$

\footnotetext{
Universidade Federal de Uberlândia, Uberlândia, MG, Brazil.

Corresponding author: Gesmar Rodrigues Silva Segundo - Department of Pediatrics, Universidade de Uberlândia - Avenida Pará, 1720 - Campus Umurama - Zip code: $38400-902$ - Uberlândia, MG, Brazil Phone: (55 34) 3236-6299 - E-mail: gesmar@famed.ufu.br

Received on: Sep 23, 2014 - Accepted on: Feb 8, 2015

Conflict of interest: none.

DOI: 10.1590/\$1679-45082015A03266
} 
Esophageal eosinophilia is the histological finding of eosinophils in an esophageal biopsy that requires interpretation in the clinical context, since it alone does not set the diagnosis of EE. Other clinical conditions may present with eosinophilia, such as gastroesophageal reflux disease (GERD) and esophageal eosinophilia responsive to PPI. ${ }^{(1)}$

Cerebral palsy patients often show dysfunction of the gastrointestinal tract, such as swallowing disorder, rumination, GERD, delayed gastric emptying and constipation. ${ }^{(4-6)}$ GERD occurs in 20 to $90 \%$ of cases depending on the criteria used ${ }^{(4)}$ and swallowing disturbances occur in up to $90 \%$ of cases. ${ }^{(5)}$ All these problems can contribute to feeding difficulties and impaired nutritional status. ${ }^{(6)} \mathrm{EE}$ could overlap these very common gastrointestinal disorders in these patients, and might not be suspected of bringing greater loss of nutrition and lower quality of life for that patient.

\section{OBJECTIVE}

To describe the clinical picture, test results, and clinical evolution of patients with cerebral palsy associated with diagnosis of eosinophilic esophagitis, monitored at tertiary centre.

\section{METHODS}

This was a cross-sectional, retrospective, and descriptive study performed in the Pediatric Gastroenterology Clinic of Hospital de Clínicas of Universidade Federal de Uberlândia, through records of patients with diagnoses of cerebral palsy and EE, from August 2005 to August 2013. Data were related to age, sex, age at diagnosis, symptoms, endoscopic and pathological changes. Other tests performed such as pHmetry and allergy tests, treatments performed, diet, feeding type, presence or absence of antireflux valve and evolution were collected. This study was approved by the Research Ethics Committee of the organization (protocol number 759/09). Since it is a retrospective study, informed consent was not necessary. The descriptive statistics were used to present the data.

\section{RESULTS}

In a survey of the medical files of 136 patients with cerebral palsy treated in our clinic, 7 patients with associated EE were found. Of the total, four were male $(57 \%)$. The age of the patients at the time of analysis ranged from 70 to 156 months with an average of 104.7 months. Prematurity associated with perinatal asphyxia was the cause of cerebral palsy in four patients (57.1\%), bilirubin encephalopathy in two $(28.6 \%)$ patients and in one patient $(14.3 \%)$, the cause was not related to the perinatal period but herpetic encephalitis at preschool age.

Patients with cerebral palsy presenting gastrointestinal symptoms underwent esophagogastroduodenoscopy (EGD) with biopsies. All patients had suggestive endoscopic changes in the examination that detected esophageal eosinophilia on histologic analyses. The age of detection of esophageal eosinophilia in patients ranged from 23 to 112 months, with a mean of 52.3 months. The number of eosinophils in the esophagus at diagnosis ranged from 20 to 50 eosinophils/hpf with an average of 35 eosinophils. The clinical cases are summarized in table 1. The symptoms presented by patients are shown in table 2 , the changes found in endoscopies are described in table 3 , and the results of immunologic tests are described in table 4.

Table 1. Clinical data of pediatric patients with cerebral palsy and suspicion of eosinophilic esophagitis

\begin{tabular}{|c|c|c|c|c|c|c|c|}
\hline Data/patients & Case 1 & Case 2 & Case 3 & Case 4 & Case 5 & Case 6 & Case 7 \\
\hline Age $(m)$ & 78 & 122 & 156 & 105 & 70 & 84 & 118 \\
\hline Sex & Male & Female & Male & Female & Male & Female & Male \\
\hline Age at detection $(\mathrm{m})$ & 42 & 65 & 112 & 50 & 35 & 39 & 23 \\
\hline Symptoms & $\begin{array}{l}\text { Vomiting, low weight } \\
\text { gain and dysphagia }\end{array}$ & $\begin{array}{l}\text { Vomiting, low } \\
\text { weight gain and } \\
\text { abdominal pain }\end{array}$ & $\begin{array}{l}\text { Abdominal and } \\
\text { generalized pain }\end{array}$ & $\begin{array}{c}\text { Vomiting, low } \\
\text { weight gain and } \\
\text { dysphagia }\end{array}$ & Dysphagia & $\begin{array}{l}\text { Vomiting, } \\
\text { abdominal pain } \\
\text { and distension }\end{array}$ & $\begin{array}{l}\text { Vomiting, chronic cough and } \\
\text { dysphagia }\end{array}$ \\
\hline Endoscopy findings & $\begin{array}{c}\text { Distal mucosa pallor } \\
\text { and thickening with } \\
\text { granulations and } \\
\text { furrows }\end{array}$ & $\begin{array}{c}\text { Mucosa } \\
\text { hyperemia, } \\
\text { distal erosion }\end{array}$ & Not available & $\begin{array}{l}\text { Distal mucosa } \\
\text { thickening and } \\
\text { furrows }\end{array}$ & $\begin{array}{l}\text { Distal mucosa } \\
\text { pallor and } \\
\text { thickening }\end{array}$ & $\begin{array}{l}\text { Distal thin } \\
\text { and white } \\
\text { granulations }\end{array}$ & $\begin{array}{l}\text { Pallor and thickening } \\
\text { mucosa, furrows and white } \\
\text { plaques (so-called crêpe- } \\
\text { paper mucosa) }\end{array}$ \\
\hline Pathologic findings (Eo/hpf) & 32 & $>50$ & $>50$ & 40 & 33 & $>30$ & 22 \\
\hline Phmetry (RI/De Meester) & NA & $8.1 \% / 22.7$ & NA & $24.3 \% / 96.3$ & $6 \% / 18.3$ & $22.9 \% / 79.1$ & Normal \\
\hline Feeding method upon diagnosis & GTM & Oral & GTM & GTM & Oral & Oral & Oral \\
\hline
\end{tabular}


....Continuation

Table 1. Clinical data of pediatric patients with cerebral palsy and suspicion of eosinophilic esophagitis

\begin{tabular}{|c|c|c|c|c|c|c|c|}
\hline Data/patients & Case 1 & Case 2 & Case 3 & Case 4 & Case 5 & Case 6 & Case 7 \\
\hline Antireflux valve & NA & Nissen & NA & NA & Nissen & Nissen & Nissen \\
\hline Clinic/pathologic response to PPI & Absent & Absent & Absent & Present & Absent & Absent & Present \\
\hline Diet & $\begin{array}{c}\text { Amino acid-based } \\
\text { formula, extensively } \\
\text { hydrolysed formula, and } \\
\text { complementary feeding }\end{array}$ & $\begin{array}{l}\text { Soy formula and } \\
\text { complementary } \\
\text { feeding }\end{array}$ & $\begin{array}{l}\text { Amino acid- } \\
\text { based formula, } \\
\text { extensively } \\
\text { hydrolysed } \\
\text { formula, and } \\
\text { complementary } \\
\text { feeding }\end{array}$ & Egg exclusion & Free diet & Free diet & $\begin{array}{c}\text { Amino acid-based formula } \\
\text { and complementary feeding. } \\
\text { Egg exclusion }\end{array}$ \\
\hline Pre-diagnosis drugs & $\begin{array}{l}\text { PPI, ranitidine and } \\
\text { domperidone }\end{array}$ & $\begin{array}{l}\text { PPI and } \\
\text { cisapride }\end{array}$ & PPI & $\begin{array}{l}\text { PPI, } \\
\text { ranitidine and } \\
\text { domperidone }\end{array}$ & $\begin{array}{l}\text { PPI, } \\
\text { ranitidine and } \\
\text { domperidone }\end{array}$ & $\begin{array}{l}\text { PPI, } \\
\text { ranitidine and } \\
\text { domperidone }\end{array}$ & $\begin{array}{l}\text { PPI, ranitidine and } \\
\text { domperidone }\end{array}$ \\
\hline Post-diagnosis drugs & PPI & Fluticasone & Fluticasone, PPI & PPI & Fluticasone & Fluticasone & Budesonide \\
\hline
\end{tabular}

m: month; Eo/hpf: eosinophils per high-power field; RI: reflux index; NA: not applicable; GTM: gastrostomy; PPI: proton pump inhibitor

Table 2. Clinical symptoms in patients with cerebral palsy and eosinophilic esophagitis diagnosis in a tertiary center of pediatric gastroenterology

\begin{tabular}{ll}
\hline Symptoms & $\mathbf{n}(\%)$ \\
\hline Recurrent vomiting & $5(71.4)$ \\
Dysphagia & $4(57.1)$ \\
Failure to thrive* & $3(42.8)$ \\
Abdominal Pain & $3(42.8)$ \\
Diffuse pain & $1(14.3)$ \\
Chronic cough & $1(14.3)$ \\
\hline
\end{tabular}

* Weight and height less than the 10th percentile in comparison with Brooks et al. curve; anthropometric data in percentiles according to the references by Brooks et al. for individuals with cerebral palsy (Brooks J, Day S, Shavelle R, Strauss D. Low weight, morbidity, and mortality in children with cerebral palsy: new clinical growth charts. Pediatrics. 2011;128(2)::299-307.

Table 3. Endoscopic changes in patients with cerebral palsy and eosinophilic esophagitis diagnosis in a tertiary center of pediatric gastroenterology

\begin{tabular}{lc}
\hline Endoscopic alterations & $\mathbf{n}(\%)$ \\
\hline Mucosal thickening & $4(57.1)$ \\
Vertical lines & $4(57.1)$ \\
Mucosal opacificacion & $3(42.9)$ \\
White plaques & $3(42.9)$ \\
Mucosal hyperemia & $1(14.3)$ \\
\hline
\end{tabular}

Table 4. Results of immunologic tests of patients with cerebral palsy and eosinophilic esophagitis

\begin{tabular}{|c|c|c|c|c|c|c|c|}
\hline & Case 1 & Case 2 & Case 3 & Case 4 & Case 5 & Case 6 & Case 7 \\
\hline Total lgE & 25.7 & 108 & NA & NA & NA & NA & NA \\
\hline $\begin{array}{l}\text { Patch test (milk, egg, } \\
\text { soy, wheat and corn) }\end{array}$ & Negative & Negative & NA & Negative & Negative & Negative & NA \\
\hline $\begin{array}{l}\text { Prick test (milk, egg, soy, } \\
\text { wheat and corn) }\end{array}$ & NA & NA & NA & NA & Negative & NA & NA \\
\hline Specific lgE to cow's milk & $<0.1$ & $<0.35$ & NA & 0.2 & NA & 0.92 & $<0.35$ \\
\hline Specific lgE to egg white & 0.19 & $<0.35$ & NA & 8.58 & NA & 9.99 & 4.91 \\
\hline Specific lgE to egg yolk & 0.14 & $<0.35$ & NA & 5.24 & NA & 5.54 & 0.65 \\
\hline Specific lgE to soy & 0.76 & $<0.35$ & NA & $<0.1$ & NA & 0.24 & 0.49 \\
\hline Specific lgE to wheat & 0.76 & $<0.35$ & NA & $<0.1$ & NA & $<0.1$ & 0.36 \\
\hline
\end{tabular}

\section{Case 1}

LSS, 6-year-old male, presented vomiting, low weight gain and dysphagia since infancy with no clinical response to drug treatment of GERD. The patient underwent an endoscopic gastrostomy at 12 months of age, with no improvement of symptoms. The endoscopy showed distal mucosa pallor, thickening with granulations, and furrows. A biopsy showed eosinophilia restricted to the esophagus (32 eosinophils/hpf), which persisted after a course of high-dose PPI for over 8 weeks ( $>50$ eosinophils/hpf). A skin prick test for main food allergens was negative. An elemental diet was undertaken with clinical improvement, but no histological resolution was observed. The patient was considered inappropriate for the treatment with inhaled corticosteroids (swallowed) due to his severe swallowing disorder.

\section{Case 2}

RCL, 10-year-old female who presented low weight gain from birth, associated with abdominal pain and frequent vomiting between 12 and 24 months, with no improvement with GERD treatment. At 24 months of age, she received nasogastric feeding with partial improvement of weight gain. After the age of 5, she had several EGDs with biopsies detecting esophageal eosinophilia and rare eosinophils in the duodenal mucosa with use of PPI at low doses. At 8 years of age, she received a course of PPI at high doses for longer than 8 weeks and maintained esophageal eosinophilia (25 to 50 eosinophils/hpf). The endoscopy showed mucosal hyperemia and distal erosion. She also tried to use corticosteroids (swallowed), but it was discontinued due to a swallowing disorder. The oesophageal $\mathrm{pH}$ monitoring ( $\mathrm{pH}$-metry) result was suggestive of GERD. Allergy tests were negative. The patient underwent 
gastrostomy and antireflux surgery at 9 years of age with total regression of clinical manifestations and histological eosinophilia.

\section{Case 3}

LALS, 13-year-old male, with gastrostomy from age 6 years due to a swallowing disorder, chronic abdominal pain and vomiting. At age 9 years, he underwent an EGD with histological examination that detected esophageal eosinophilia ( $>50$ eosinophils/hpf) and frequent eosinophils in the duodenal mucosa. The results of the EGD were not available. He had a course of PPI with an approximate dose of $2 \mathrm{mg} / \mathrm{kg}$ /day and inhaled corticosteroids (swallowed) with persistent eosinophilia. He showed reduction of vomiting with PPI, and improvement of pain after excluding cow's milk from his diet. He had negative skin prick tests. Some time later, he returned with abdominal pain and had an elemental diet initiated, showing good clinical and histological response (absence of eosinophils on endoscopy). He is maintaining clinical remission after reintroduction of cow's milk in the diet.

\section{Case 4}

VTS, 8-year-old female, presented low weight gain, vomiting and dysphagia since infancy with partial clinical response to treatment of GERD. She also presented recurrent pneumonia. She underwent gastrostomy at age 2 due to a swallowing disorder. At 8 years of age, she had an EGD that showed a distal mucosa thickening and furrows. The histological analysis detected esophageal eosinophilia (40 eosinophils/hpf), which remitted after a course of PPI with an approximate dose of $2 \mathrm{mg} / \mathrm{kg} / \mathrm{day}$ for 8 weeks ( 5 eosinophils/hpf) associated with clinical improvement during use. She had hives immediately after eating egg with specific IgE to egg white and egg yolk of 8.58 and 5.24, respectively, and a negative atopy patch test for main food allergens. After discontinuation of PPI and maintenance of an egg-exclusion diet, she showed a relapse of esophageal eosinophilia (70 eosinophils/hpf). The result of $\mathrm{pH}$-metry was suggestive of GERD. A treatment with corticosteroids (swallowed) was initiated.

\section{Case 5}

CHMM, 5-year-old male, presented severe swallowing disorder with two aspiration pneumonias. The result of pH-metry was suggestive of GERD and EGD, which showed a distal mucosal pallor and thickening. The histological analysis detected esophageal eosinophilia
(33 eosinophils/hpf) at the age of 2 . A course of PPI with dose of $2 \mathrm{mg} / \mathrm{kg} /$ day was prescribed for more than 8 weeks, but maintained esophageal eosinophilia ( $>20$ eosinophils/hpf). Allergy skin tests were negative. He was treated with inhaled corticosteroids (swallowed) and PPI at low doses, showing clinical and histological remission at a later endoscopy. At 4 years of age, he was submitted to gastrostomy with surgical correction of reflux that resulted in clinical improvement.

\section{Case 6}

ISR, 7-year-old female who presented vomiting, abdominal pain and distension from 2 months of age with partial clinical response to PPI and use of an elemental diet. She developed hives and vomiting after ingestion of cow's milk and egg with specific IgE to cow's milk, egg white and egg yolk $-1.26 \mathrm{Ku} / \mathrm{L}, 9.99 \mathrm{Ku} / \mathrm{L}$ and $5.54 \mathrm{Ku} / \mathrm{L}$, respectively. A food allergy was confirmed by oral challenge. She underwent an atopy patch test for main food allergens, which was negative. At 2 years of age, the EGD showed distal mucosal thinning with white granulations. Esophageal eosinophilia was detected ( $>30$ eosinophils/hpf), which persisted after a course of PPI in a dose of $<2 \mathrm{mg} / \mathrm{kg} /$ day and an elemental diet (22 eosinophils/hpf). The result of $\mathrm{pH}$-metry was suggestive of GERD. She was submitted to gastrostomy with surgical correction of reflux at age 5 , with total clinical and histological remission at endoscopy 2 months later (0 eosinophil/hpf).

\section{Case 7}

JWF, 9-year-old male, presented vomiting, dysphagia and chronic cough, especially after feeding, since infancy. $\mathrm{He}$ received treatment for GERD with a diet excluding cow's milk, without clinical response. The result of $\mathrm{pH}$ metry did not show alterations. The first EGD showed a pallor and thickening mucosa, furrows, and white plaques, and the histological examination at age 2 showed esophageal eosinophilia (22 eosinophils/hpf), which remitted after a course of IBP at low doses and the use of inhaled corticosteroids (swallowed) (12 eosinophils/hpf), but without clinical improvement. An IgE test detected egg white of 4.91. As he presented persistent symptoms, endoscopy with biopsies was repeated with the use of PPI at high doses for 8 weeks; an exclusion diet of egg and cow's milk was carried out, with histological remission (0 eosinophil/hpf), but with persistent vomiting and a sporadic cough. He was submitted to gastrostomy and surgical correction of reflux at age 7 , showing clinical improvement. Although 
the new endoscopy with biopsies after the procedure showed a recurrence of esophageal eosinophilia only in distal third (20 eosinophils/hpf), he started viscous budesonide with improvement of eosinophilia.

\section{DISCUSSION}

Esophageal eosinophilia is a histological finding that should be interpreted in the clinical setting. More than one disease could be involved in this tissue inflammation. In an isolated esophageal eosinophilia finding, three main conditions must be suspected: GERD, PPI-responsive esophageal eosinophilia, and eosinophilic esophagitis. ${ }^{(7,8)}$ The evaluation of patients with cerebral palsy and esophageal eosinophilia should be performed carefully to establish if a diagnosis of $\mathrm{EE}$ is appropriate or not. A misdiagnosis or a delayed diagnosis could impede the patient's adequate treatment, and therefore, a better quality of life. On the other hand, an over diagnosis could add another disease to the patient's history, also interfering in his and his family's quality of life.

All patients in this study had symptoms related to esophageal dysfunction and esophageal eosinophilic inflammation with at least 15 eosinophils/hpf, which are initial criteria for the diagnosis of eosinophilic esophagitis. However, not all patients met the other criteria for the diagnosis of this entity. ${ }^{(1)}$

Cases 1, 2, 3, 5 and 7 showed clinical development and tests consistent with the diagnosis of EE with persistent esophageal eosinophilia after a course of PPI in a dose of $2 \mathrm{mg} / \mathrm{kg} /$ day or more for, at least, 8 weeks. The patient in case 2 met the criteria for diagnosis of EE but improved clinically and histologically after gastrostomy and antireflux surgery, leaving doubt about the diagnosis of EE. On the other hand, case 4 showed histological remission after PPI at high doses, as the diagnoses of PPI-responsive esophageal eosinophilia or GERD were more appropriate for this patient. Indeed, considering the result of $\mathrm{pH}$-metry, the diagnosis of GERD is even more appropriate. Furthermore, in case 6 there was not an adequate PPI dose to establish diagnosis of EE. Besides, correlating the result of pH-metry and clinical and histological remission after gastrostomy and antireflux surgery, it would be reasonable to attribute the findings to a case of GERD. In case 7 , the exclusion of foods associated with a food allergy together with use of PPI at high doses were performed, and therefore, we do not know which action was responsible for improvement. This patient also had clinical improvement after gastrostomy and antireflux surgery, but again showed esophageal eosinophilia during his evolution, effectively consistent with EE diagnosis.

Eosinophils were described in the duodenal mucosa biopsy in cases 2 and 3 - rare and frequent eosinophils, respectively. The presence of eosinophils in other parts of the gastrointestinal tract beyond the esophagus may occur, and the cutoff for suspicion of eosinophilic gastroenteritis is 20 eosinophils/hpf. However, in both cases, there was no pathological description of the eosinophils count to confirm whether it is a normal or altered number for the duodenal region. ${ }^{(9)}$

The diagnosis of EE seemed appropriate for cases $1,2,3,5$ and 7, but not appropriate in cases 4 and 6 .

Recent published studies confirmed that gastrointestinal disorders are a major chronic problem in most children with cerebral palsy or neurodevelopmental disabilities. ${ }^{(10)}$ GERD should be suspected due to its frequency in this population, but other conditions must be suspected also, according to the clinical presentation and evolution. In a previous study before the recognition of $\mathrm{EE}$ as a disease, the authors concluded that in neurologically impaired children who are unresponsive to conventional antireflux treatments, a course of a highly restricted diet with an amino acid-based formula may bring an immediate and sustained, endoscopically and histologically proven improvement in long-standing gastrointestinal symptoms and esophagitis. This improvement probably occurred because the diagnosis for these patients could be EE. ${ }^{(11)}$ Moreover, the frequency of EE in patients with cerebral palsy found in this study was elevated compared to the presence of EE in the general population..$^{(1,12,13)}$

In a recent consensus published in 2013, because of the difficulty in performing the exclusion diets and the impact of these diets on the patient's quality of life, it was suggested that patients received initial treatment with swallowed corticosteroids to control symptoms and inflammation; and if controlling this is not achieved, research into food allergies should be conducted to exclude suspected foods. ${ }^{(1)}$ However, this consensus and other studies maintain the possibility of initial treatment with an elimination diet (elemental, Kagalwalla, or directed) according to the experience of each medical unit. $^{(1,12-14)}$ In our view, most patients with cerebral palsy are gastrostomyzed, and this fact makes exclusion diets less traumatic. They receive the feeding through probes, which reduces the impact of poor acceptance. Besides, the high prevalence of swallowing disorders in these patients becomes a problem for the use of swallowed corticosteroids.

Children with cerebral palsy or other neurodevelopmental disabilities with suspected EE should be investigated as normal patients, considering the latest recommendations 
for $\mathrm{EE}$ that have received great attention from physicians, which therefore, has resulted in rapidly growing knowledge about this disease. ${ }^{(15-18)}$

Despite the diagnosis of $\mathrm{EE}$, this population has some particularities that should be considered as a result of the new finding of esophageal eosinophilia. In 2008, the literature described cases of anticonvulsivant hypersensitivity syndrome, which shows a severe and unusual reaction to antiepileptic agents that can have esophageal eosinophilia as a component. ${ }^{(19)}$ Patients with cerebral palsy usually have chronic use of anticonvulsant drugs, making this diagnosis an important possibility of esophageal eosinophilia.

One of the limitations of this study was its retrospective format, which did not allow data systematization with several procedures and other occurrences in each patient. Another limitation was the selection criteria of patients, which was the result of the diagnostic crossing in an automated system, and did not allow the analysis of the number of patients with cerebral palsy who underwent endoscopy or had other diagnoses confirmed as GERD. Nonetheless, the findings related to EE in this group of patients were relevant in relation to their frequency and novelty.

\section{CONCLUSION}

The diagnosis of eosinophilic esophagitis is very important in patients with cerebral palsy and should be done carefully, taking into account the regular criteria, since the frequency of eosinophilic esophagitis in patients with cerebral palsy found in this study was elevated, compared with the presence of eosinophilic esophagitis in the general population. Furthermore, the treatment of these patients should also take into account their particularities, including swallowing disorder and alternative feeding means, with the possibility of performing exclusion diets as a reasonable option. Further studies are needed to establish specific diagnosis and treatment in patients with cerebral palsy and esophageal eosinophilia.

\section{REFERENCES}

1. Dellon ES, Gonsalves N, Hirano I, Furuta GT, Liacouras CA, Katzka DA; American College of Gastroenterology. ACG clinical guideline: Evidenced based approach to the diagnosis and management of esophageal eosinophilia and eosinophilic esophagitis (EoE). Am J Gastroenterol. 2013;108(5):679-92.

2. Landres RT, Kuster GG, Strum WB. Eosinophilic esophagitis in a patient with vigorous achalasia. Gastroenterology. 1978;74(6):1298-301.

3. Attwood SE, Smyrk TC, Demeester TR, Jones JB. Esophageal eosinophilia with dysphagia. A distinct clinicopathologic syndrome. Dig Dis Sci. 1993; 38(1):109-116

4. Spiroglou K, Xinias I, Karatzas N, Karatza E, Arsos G, Panteliadis C. Gastric emptying in children with cerebral palsy and gastroesophageal reflux. Pediatr Neurol. 2004;31(3):177-82.

5. Calis EA, Veugelers R, Sheppard JJ, Tibboel D, Evenhuis HM, Penning C. Dysphagia in children with severe generalized cerebral palsy and intellectual disability. Dev Med Child Neurol. 2008;50(8):625-30.

6. Thomson M, Rao P, Rawat D, Wenzl TG. Percutaneous endoscopic gastrostomy and gastroesophageal reflux in neurologically impaired children. World $J$ Gastroenterol. 2011;17(2):191-6.

7. Ngo P, Furuta GT, Antonioli DA, Fox VL. Eosinophils in the esophagus - peptic or allergic eosinophilic esophagitis? Case series of three patients with esophageal eosinophilia. Am J Gastroenterol. 2006;101 (7):1666-70.

8. Molina-Infante J, Ferrando-Lamana L, Fernandez-Bermejo M, Porcel-Carreño S. Eosinophilic esophagitis in GERD patients: a clinicopathological diagnosis using protein pump inhibitors. Am J Gastroenterol. 2009;104(11):2856-7.

9. Lima J, Rebelo M, Castellano A, Mota J, Ruivo C, Dias P, et al. Gastroenterite eosinofílica, divertículo duodenal intraluminal como fator predisponente? GE J PortGastroenterol. 2012;19(3):146-50.

10. Gonzalez Jiménez D, Díaz Martins JJ, Bousoño García C, Jiménez Treviño S. [Gastrointestinal disorders in children with cerebral palsy and neurodevelopmental disabilities]. An Pediatr (Barc). 2010;73(6):361.e1-361.e6. Spanish.

11. Miele E, Staiano A, Tozzi A, Auricchio R, Paparo F, Troncone R. Clinical response to amino acid-based formula in neurologically impaired children with refractory esophagitis. J Pediatr Gastroenterol Nutr. 2002;35(3):314-9.

12. Assa'ad AH, Putnam PE, Collins MH, Akers RM, Jameson SC, Kirby CL, et al. Pediatric patients with eosinophilic esophagitis: an 8-year follow-up. J Allergy Clin Immunol. 2007;119(3):731-8.

13. Davis BP, Rothenberg ME. Emerging concepts of dietery therapy for pediatric and adult eosinophlic esophagitis. Expert Rev Clin Immunol. 2013;9(4):285-7. Review.

14. Rezende ER, Barros CP, Ynoue LH, Santos AT, Pinto RM, Segundo GR. Clinical characteristics and sensitivity to food and inhalants among children with eosinophilic esophagitis. BMC Res Notes. 2014;7:47.

15. Wolf WA, Jerath MR, Dellon ES. De-novo onset of eosinophilic esophagitis after large volume allergen exposures. J Gastrointestin Liver Dis. 2013;22(2):205-8.

16. Rodrigues M, D'Amico MF, Patiño FR, Barbieri D, Damião A0, Sipahy AM. Clinical manifestations, treatment, and outcomes of children and adolescents with eosinophilic esophagitis. J Pediatr (Rio J). 2013;89(2):197-203.

17. Dellon ES, Gibbs WB, Fritchie KJ, Rubinas TC, Wilson LA, Woosley JT, et al. Clinical, endoscopic, and histologic findings distinguish eosinophilic esophagitis from gastroesophageal reflux disease. Clin Gastroenterol Hepatol. 2009;7(12):1305-13; quiz 1261.

18. Lee JH, Kim MJ, Kim JH, Youn YH, Kim N, Bak YT, et al. Clinical analysis of primary eosinophilic esophagitis. J Neurogastroenterol Motil. 2013;19(2):204-9.

19. Balatsinou C, Milano A, Caldarella MP, Laterza F, Pierdomenico SD, Cuccurullo F, et al. Eosinophilic esophagitis is a component of the anticonvulsivant hypersensitivity syndrome: description of two cases. Dig Liver Dis. 2008; 40(2):145-8. 